Original Research Paper

\title{
Experimental Trails on Diesel Engine Performance and Emission Characteristics of Waste Cooking Oil Combinations at Varying Injection Pressures
}

\author{
Abdullah Al-Ghafis and M. Shameer Basha \\ Department of Mechanical Engineering, College of Engineering, Unaizah, Qassim University, Saudi Arabia
}

\author{
Article history \\ Received: 19-09-2020 \\ Revised: 16-01-2021 \\ Accepted: 20-01-2021 \\ Corresponding Author: \\ Abdullah Al-Ghafis \\ Department of Mechanical \\ Engineering, College of \\ Engineering, Unaizah, Qassim \\ University, Saudi Arabia \\ Email: a.alghafis@qu.edu.sa
}

\begin{abstract}
Progressive rising of conventional fuel prices, as well as the high strengthened necessities of the environmental norms to reduce the atmospheric pollution levels, are flattering great challenges to scientists and researchers all over the world. In this regard, biofuels have become one of the best alternative fuels for conventional IC engine operation with reduced emissions and improved performance. Goal of paper is to study the influence on emissions and performance variables in onecylinder CI engine fueled accompanied by diesel-waste cooking oil mixtures. The test rig was operated at rated speed $1500 \mathrm{rpm}, \mathrm{CR} 17.5$ and at variable injection operating pressure of 200, 225 and 250 bar correspondingly. Different fuel mixtures of diesel-waste cooking oil i.e., B10, B20 and B30 on mass basis were used for this study. As compared to neat diesel at standard Injection Operating Pressure (IOP) 200 bar, increased IOP 225 bar exhibits utmost BTE, nominal quantity $\mathrm{BSFC}$, minimum $\mathrm{CO}$ and $\mathrm{HC}$ pollutions with the superior concentration of NOx emissions. In contrast, by using WCO blends, the performance of the engine reduced along with the emissions except $\mathrm{HC}$.
\end{abstract}

Keywords: Waste Cooking Oil, Biofuels, Injection Operating Pressures, Performance, Emissions

\section{Introduction}

Owing to glut utilization of petroleum-based fuels for automobile and manufacturing relevance in contemporary time, the world is incrusting severe complications like environmental contamination, global energy crisis and global warming. Consequently, global cognizance is propagated to avert the fuel catastrophe by emerging substitute fuel sources for engine function. Many research findings are in progress to replacement diesel fuel with a suitable substitute fuel alike biodiesel. Non-edible sources like neem, rubber seed, tobacco seed, rice bran, jatropha, karanja, mahua are being investigated for biodiesel manufacture. Among these, WCO finds similar as diesel engine fuel because of its ease of use and have striking features equivalent to diesel (Lin et al., 2011). Source like WCO was abundant all over the globe, utilized as supplement for hay mixing and soap preparation. On the other side, huge segments of WCO deserted through running water and badlands lead ecological contamination. The best possible method to get rid of WCO is by transforming into fuel and using in IC engines (Phan and Phan, 2008). The use of less-cost WCO biodiesel over in cost with petroleum products (Chhetri et al., 2008). This leads to chance for WCO to manufacture raw materials (Meng et al., 2008). Utilizing again WCO not only diminishes price of discharging the waste and dealing greasy fritter away water, also inferior making price of biodiesel significantly (Canakci, 2007). Number of scientists were illustrated that WCO blend as a substitute to diesel and decreased dangerous exhaust pollutions along with comparable increase in presentation (Valente et al., 2012). Lapuerta et al. (2008) considered dual dissimilar WCO blends and compared diesel in DICI engine. Additionally, performance is not much affected, blends utilization was raised and the smog pollutions were piercingly reduced as blends attentiveness increased. Hwang et al. (2014) assayed result of fuel injection characteristics on burning and emission individuality under full load. Above investigations on WCO blend beneficial in minimizing 
$\mathrm{CO}, \mathrm{HC}$ and smoke emissions, focuses elevated IOP. WCO blend displayed superior NOx than diesel under every service limits. Bari et al. (2004; Gumus, 2010) informed the authority in timing of injection on performance, pollutions and burning variables of CI engine utilizing diesel and WCO biodiesel. It gives that the $\mathrm{CO}$ and $\mathrm{CO}_{2}$ emissions are concentrated, yet $\mathrm{NOx}$ rises when the timing of injection highly developed. The results also showed highest cylinder pressures, rate of heat release and good combustion. Qi et al. (2011) investigated consequence timing of injection and rate of EGR on the burning and emission over ford lion V6 DICI engine utilizing biodiesel represented soya bean and concluded BSFC was somewhat higher when restarted main injection timing. NOx lowered and soot pollutions almost not diverse. Sanli et al. (2015) invented a novel numerical equation to foresee heating values of used frying oils depending on deterioration investigation. Above experiment involves 35 samples unruffled various fast-food center, hospital and restaurants. Obtained most defined conclusions using above method differentiate other formulation existing in the survey. Average fault found to be $0.37 \%$. (Muralidharan and Vasudevan, 2011) showed all Characteristics of one-cylinder DI C I engine fuelled WCO blend its $1 / 5,2 / 5,3 / 5$ and $4 / 5 \%$ by volume. Conclusions given longer delay in ignition, peak rate of pressure rise, minimum rate of heat release and huge mass-fraction burnt. Radu et al. (2009) studied on WCO biodiesel fuel (1/2\% by vol) and blend on a DI CI engine and its fuel injection system. Results showed variables of injection system found on injection pump worktable. Investigation showed propagation times of pressure wave similar with SOI lowered by rising injection duration and cyclic delivery due to various characteristics of the biodiesel i.e., higher viscosity, density and isentropic bulk modulus. This present study focuses use of WCO for its presentation as a fuel in CI engines at different IOP. In addition, the emission parameters were also studied along with performance parameters.

Table 1: Properties of waste cooking oil and diesel

\begin{tabular}{lrr}
\hline Property & Diesel & \multicolumn{1}{c}{ WCO } \\
\hline Calorific value $(\mathrm{MJ} / \mathrm{kg})$ & 42.490 & 39.60000 \\
Kinematic viscosity @ $40^{\circ} \mathrm{C}\left(\mathrm{mm}^{2} / \mathrm{s}\right)$ & 3.340 & 4.90000 \\
Auto ignition temperature $\left({ }^{\circ} \mathrm{C}\right)$ & 260.000 & 300.00000 \\
Cetane number & 51.000 & 49.00000 \\
Density@ $15.56{ }^{\circ} \mathrm{C}\left(\mathrm{kg} / \mathrm{m}^{3}\right)$ & 842.700 & 877.00000 \\
Ash content $(\%$ mass $)$ & 0.010 & 0.03000 \\
Sulfur content $(\%$ mass $)$ & 0.050 & 0.00056 \\
Flash point P.M. closed $\left({ }^{\circ} \mathrm{C}\right)$ & 62.000 & 129.00000 \\
Boiling point $(\mathrm{T} 95)\left({ }^{\circ} \mathrm{C}\right)$ & $180-360$ & 250.00000 \\
Molecular weight $(\mathrm{kg} / \mathrm{kmol})$ & 191.000 & 305.00000 \\
\hline
\end{tabular}

\section{Experimental Setup and Procedure}

\section{Engine-Instrumentation Systems}

The test-rig used is Kirloskar TV-1, fully computer interfaced, one cylinder, $\mathrm{CR}, \mathrm{H}_{2} \mathrm{O}$ cooled, 4- stroke CI engine features given in Table 2, a graphic apparatus setup is shown Fig. 1. This engine is fix to an eddy current dynamometer whose specifications are shown in Table 3, to test the load ability of the engine. Air temperature, coolant temperature sensor and throttle arrangement are fix to open electronic control unit which controls fuel injector, fuel pump and idle air. The apparatus includes other standard engine devices, for example a thermocouple to measure oil, air, inlet manifold and exhaust temperatures and pressure gauges fixed at respected points. Coolant water abounding to the engine is measured using a Rotameter. The inlet temperature and pressure were selected to give steady and knock free engine operation.

Table 2: Features of test engine

\begin{tabular}{ll}
\hline Particulars & Specifications \\
\hline Model and make & TV-1, Kirloskar oil engines \\
Type of ignition & $\mathrm{CI}$ \\
Rated power $(\mathrm{kW})$ & 3.5 \\
Maximum speed $(\mathrm{rpm})$ & 1500 \\
Bore $\times$ stroke & $87.5 \times 110 \mathrm{~mm}$ \\
Connecting rod length $(\mathrm{mm})$ & 234 \\
CR & $17.5: 1$ \\
Cylinder Capacity $(\mathrm{CC})$ & 661 \\
Fuel injection & Direct injection \\
Injection timing & $23^{\circ}$ BTDC \\
Piston bowl & Hemispherical \\
Starting & Auto start \\
Cooling & Water cooled \\
\hline
\end{tabular}

Table 3: Specifications of dynamometer

\begin{tabular}{ll}
\hline Particulars & Specifications \\
\hline Model and make & AG10, Saj Test Plant Pvt. Ltd. \\
Type & Eddy Current \\
Water inlet pressure (bar) & 1.6 \\
Torque (Nm) & 11.5 \\
Hot coil voltage max. & 60 \\
Continuous current (amps) & 5.0 \\
Cold Resistance (ohms) & 9.8 \\
\hline
\end{tabular}

Table 4: Specifications of exhaust gas analyzer

\begin{tabular}{lll}
\hline Parameter & Measuring range & Resolution \\
\hline $\mathrm{CO}(\%$ vol $)$ & $0-9.99$ & 0.001 \\
$\mathrm{O}_{2}(\%$ vol $)$ & $0-25$ & 0.100 \\
$\mathrm{CO}_{2}(\%$ vol $)$ & $0-20$ & 0.010 \\
$\mathrm{NO}_{\mathrm{x}}(\mathrm{ppm})$ & $0-5000$ & 1.000 \\
$\mathrm{HC}(\mathrm{ppm})$ & $0-1500$ & 1.000 \\
\hline
\end{tabular}




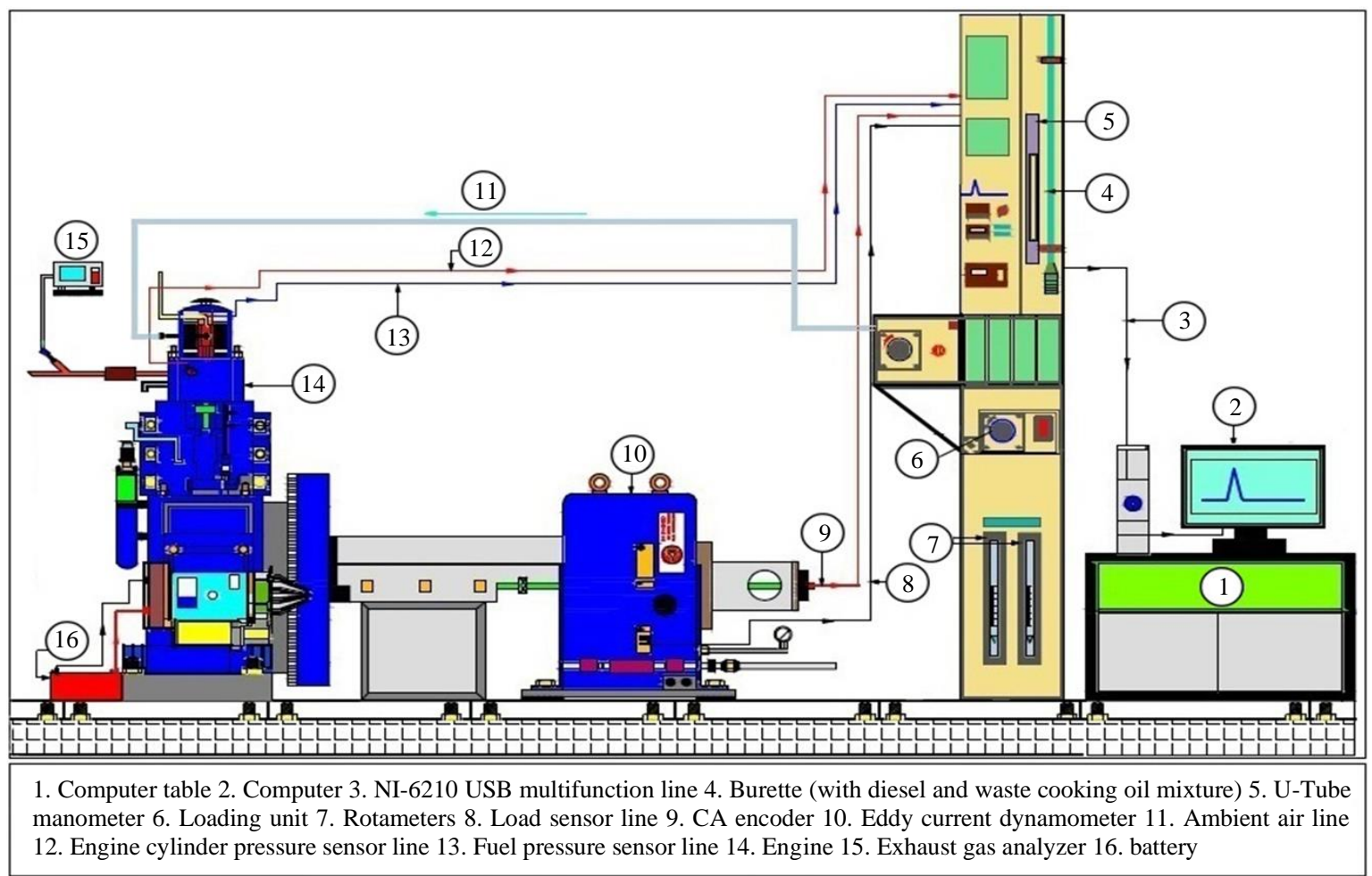

Fig. 1: Schematic WCO engine setup

Exhaust gas analyzer MN-05 (5 gas version) used to evaluate emissions. The technical specifications are shown in Table 4. It is based on infrared spectroscopy with signal inputs from an electrochemical cell. The non-dispersive infrared evaluation method is used for calculation of $\mathrm{CO}$ gas. The infrared radiation immersed by each individual gas can be utilized to compute the quantity of trial gas. Unburnt HC emissions were calculated using flame ionization principle. This principle is based on the recognition of ions formed during ignition of organic compounds. The making of these ions is comparative to the quantity of organic compounds in the test gas stream. Nitrogen oxides were calculated using chemiluminescence detector. This method relies on the quantity of light formed by the gas phase titration of nitric oxide and ozone. The calculated light is directly comparative to the amount of nitric oxide emissions.

\section{Experimental Procedure}

In the first spell, several sequence of experimental cycles performed on engine running with diesel for performance and emission parameters calculated for 3 IOP's i.e., 200, 225 and 250 bar. In second spell of experiments, the engine operated with diverse blends of WCO i.e., $0.5 / 5,1 / 5$ and $1.5 / 5 \%$ on mass basis at three unlike injection pressures. All experiments carried out under stable speed of $1500 \mathrm{rpm}$, CR17.5 and at full load. Injection timing set to a value of $23^{\circ}$ Before Top Dead
Center (BTDC). Digital shaft encoder utilized to calculate crankshaft position. The signals from piezo sensors and the crank encoder were assimilated by national instruments logical card. Data achievement was done using National Instruments Lab VIEW acquisition system developed in-house. Resulted performance and emission parameters compared.

\section{Results and Discussion}

The effects of variable diesel and WCO blends on the performance and emissions characteristics of CI engine have been studied under-stable engine speed of $1500 \mathrm{rpm}$, variable IOP and CR of 17.5. The graphs of emissions and performance characteristics have been drawn to match up to the behavior of diesel and WCO blends against pure diesel operation at different IOP.

\section{Energy Share}

In twin fuel operated engine, energy share of induced oil is vital parameter for estimating pre-mixed lean burning. To build up required quantity of power, both diesel and waste cooking oil contribute energy (Barik and Murugan, 2014a). During burning, the expenditure of diesel and WCO changes with alteration in IOP. Energy share robustly influenced by rate of fuel expenditure, calorific value, time of burning, rate of combustion (Barik and Murugan, 2014b). 


\section{Energy Shares by Neat Diesel Oil and WCO}

Energy shares by neat Diesel oil and WCO formulae as follows:

$$
\text { Energy Equivalent to Diesel }=\dot{m}_{\text {Diesel }} \times L H V_{\text {Diesel }}
$$

Energy Equivalent to Waste Cooking Oil $=\dot{m}_{\dot{w} C O} \times L H V_{w C O}$

Energy share by Diesel $=\frac{\text { Energy ewuilant to Diesel }}{\text { Energyequilant to Diesel }+ \text { energyequilant to WCO }}$

Energy share by Waste Cooking Oil $=\frac{\text { Energyequilant toWCO }}{\text { Energyequilant to Diesel }+ \text { energyequilant toWCO }}$

$\dot{m}_{\text {Diesel }}, \dot{m}_{\dot{w} C O}$ are the mass flow rates of diesel and WCO respectively and LHV is the lower heating value. Energy shares of diesel and WCO with injection operating pressure of 225 bar is specified in Table 5 .

\section{Brake Thermal Efficiency (BTE)}

Figure 2 illustrates varying BTE through changing IOP 200, 225, 250 bar with diesel and WCO blends correspondingly. From the figure, it can be absorbed that as the WCO percentage in diesel increases, BTE decreases when compared with neat diesel mode at all IOP. The changes in BTE of blends mostly due to the lower calorific value of WCO compared to pure diesel (Anand et al., 2012). Also, greater viscosity and sluggish vaporization of biodiesel lead to lesser combustion which implies a decrease in BTE (Aydin and Ilkılıc, 2010). Additionally, the BTE enhance from IOP of 200 bar to 225 bar, due to high IOP, initial fuel droplets get atomized immediately evaporates due to enhanced air/fuel assimilation consequential in whole ignition (Arai et al., 1984) compared to superior dimension droplets formed at small IOP gradually evaporate. Additionally, enhance the IOP 250 bar tend to reduce BTE, because of as small in dimension droplets have less momentum and influence the fuel delivery in the air lead partial burning (Jaichandar and Annamalai, 2013). The BTE at full load at IOP 200, 225 and 250 bar was 29.78, 32.37 and $30.99 \%$ for pure diesel compared to 28.29 , 30.25 and $28.95 \%$ for B10 (90D +10WCO), 26.8, 28.65 and $27.13 \%$ with B20 (80D +20WCO) and 25.31, 27.32 and $25.79 \%$ with $\mathrm{B} 30(70 \mathrm{D}+30 \mathrm{WCO})$ respectively.

Table 5: Energy shares of diesel and WCO blend at 225 bar IOP

\begin{tabular}{llllllll}
\hline $\begin{array}{l}\text { Mode of operation at } \\
\text { full load condition }\end{array}$ & IOP $($ bar) $)$ & $\begin{array}{l}\text { Mass of } \\
\text { Diesel }(\mathrm{kg} / \mathrm{h})\end{array}$ & $\begin{array}{l}\text { Mass of } \\
\text { WCO }(\mathrm{kg} / \mathrm{h})\end{array}$ & $\begin{array}{l}\text { Energy equivalent } \\
\text { to diesel }(\mathrm{kW})\end{array}$ & $\begin{array}{l}\text { Energy equivalent } \\
\text { to WCO }(\mathrm{kW})\end{array}$ & $\begin{array}{l}\text { Energy share } \\
\text { by diesel }(\%)\end{array}$ & $\begin{array}{l}\text { Energy share } \\
\text { by WCO }(\%)\end{array}$ \\
\hline Pure diesel & 225 & 1.239 & -- & 14.361 & - & 100 & -- \\
B10 (90 Diesel +10WCO) & 225 & 1.114 & 0.128 & 13.153 & 1.417 & 90.271 & 9.728 \\
B20 (80 Diesel +20WCO) & 225 & 1.032 & 0.268 & 12.189 & 2.955 & 80.484 & 19.515 \\
B30 (70 Diesel +30WCO) & 225 & 0.943 & 0.420 & 11.139 & 4.630 & 70.514 & 29.462 \\
\hline
\end{tabular}

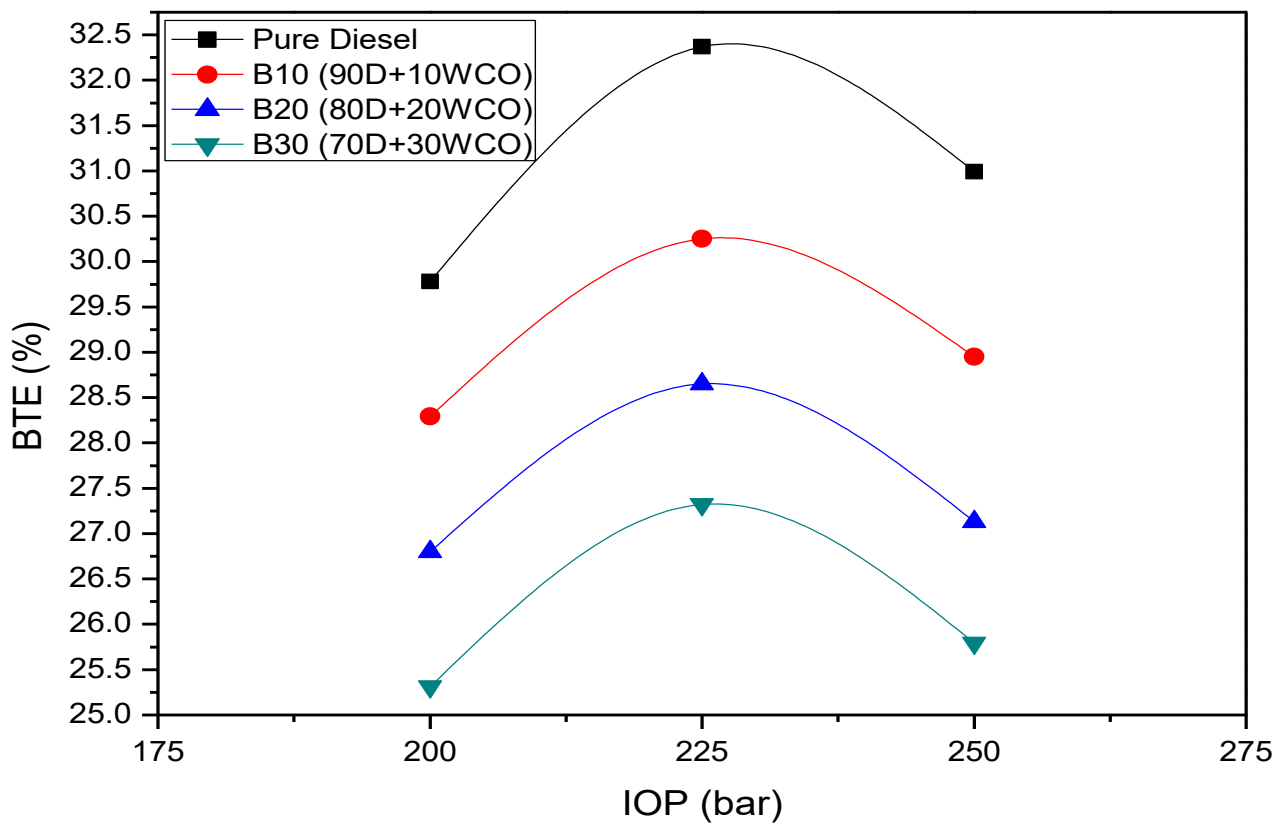

Fig. 2: Variation of BTE and IOP 


\section{Brake Specific Fuel Consumption}

While analyzing engine performance BSFC is one of the most cogent parameters that can be definite fuel flow rate per unit power output. It evaluates how effectively an engine is utilizing fuel supply to generate work. Deviation of BSFC with IOP using dissimilar fuel combination is shown in Fig. 3. It was observed that WCO\% in diesel raises, BSFC raises at all IOP. Under pure diesel mode, since the BTE was more than that of any WCO blend, hence BSFC value was smallest amount for pure diesel operation. Additionally, BSFC drop from IOP 200 to 225 bar, due to better-quality breakup of initial droplets and proper assimilation of air/fuel (Arai et al., 1984) compared to bigger size droplets shaped at low IOP gradually evaporate (Chen et al., 2013). Additional more IOP to 250 bar gives improved BSFC, this owing to poor burning and lower piercing, poor dispersion of the fuel and weak air entrainment (Kuti et al., 2013). The BSFC at full load for IOP of 200, 225 and 250 bar is $0.34,0.26$ and $0.28 \mathrm{~kg} / \mathrm{kWh}$ with pure diesel when compared to $0.37,0.28$ and $0.31 \mathrm{~kg} / \mathrm{kWh}$ for B10 (90D +10WCO), $0.42,0.32$ and $0.35 \mathrm{~kg} / \mathrm{kWh}$ with B20 $(80 \mathrm{D}+20 \mathrm{WCO})$ and $0.45,0.35$ and $0.38 \mathrm{~kg} / \mathrm{kWh}$ with B30 (70D $+30 \mathrm{WCO}$ ) respectively.

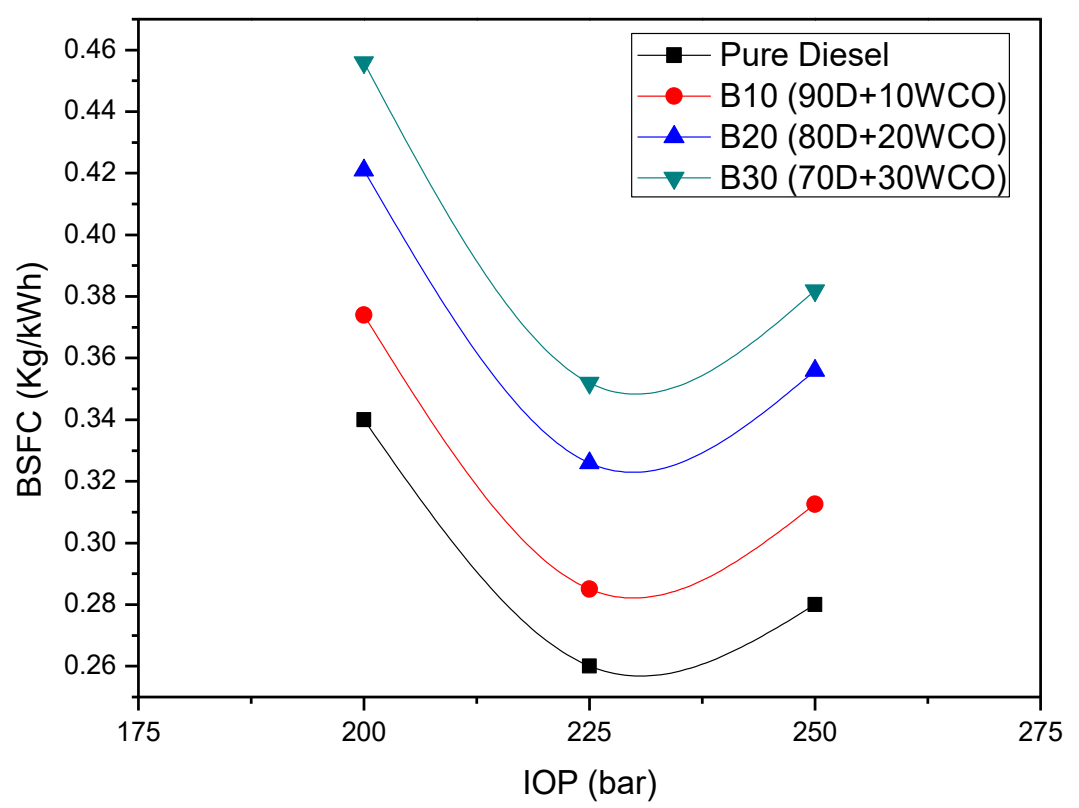

Fig. 3: Variation of BSFC and injection operating pressures

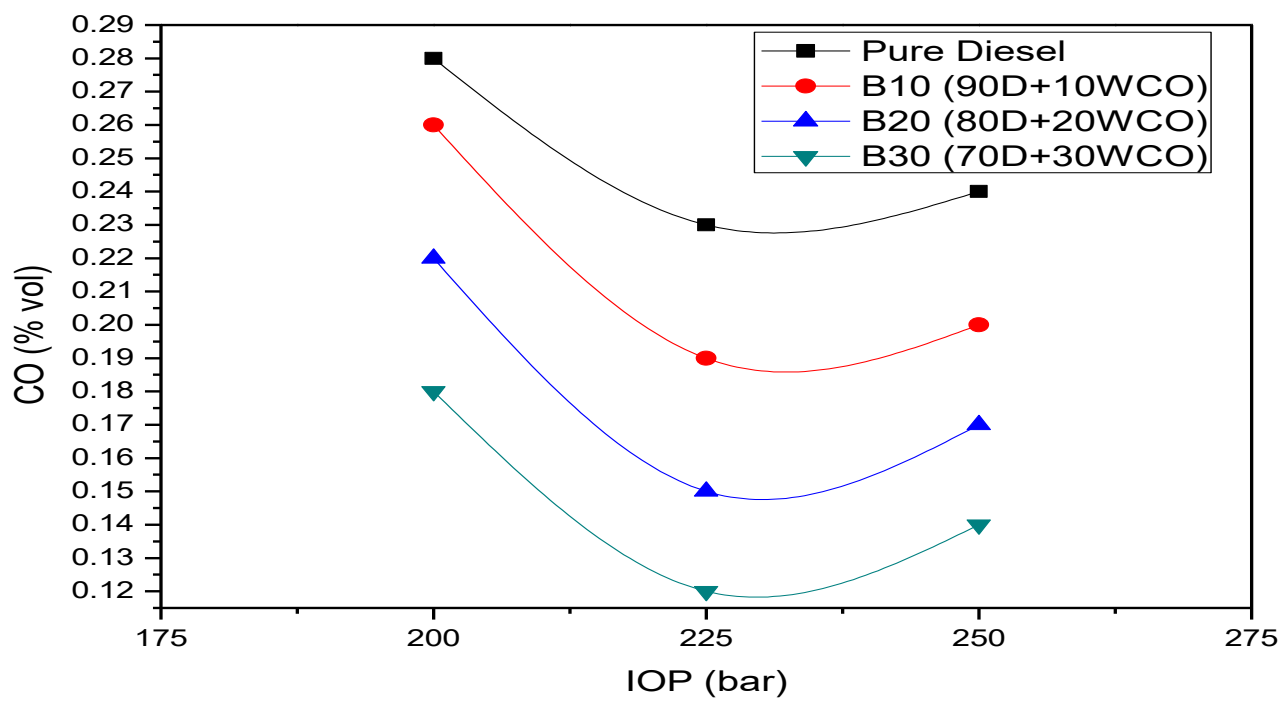

Fig. 4: Variation of $\mathrm{CO}$ emissions with injection operating pressures 


\section{Carbon Monoxide Emissions}

Figure 4 illustrates $\mathrm{CO}$ emission distinctiveness of WCO blends with injection working pressures. As the percentage substitutions of WCO in diesel increases, the $\mathrm{CO}$ emissions decrease at all IOP compared to diesel mode. The main motive for the reduced $\mathrm{CO}$ emissions is owing to the least amount carbon content present in the WCO biodiesel. Additional, the $\mathrm{CO}$ emission reduces with amplify in IOP. This may be due to fuel is breakdown into very-fine droplets and more surface area accessible for burning results in the arrangement of superior class fuel combination causes whole burning (Sayin et al., 2010). Whereas for pressure 250 bar the presentation drop leading to unfinished combustion which results in an increase $\mathrm{CO}$ at full load. The lower amount $\mathrm{CO}$ was noticed for B30 (70D +30WCO) at 225 bar i.e., $0.12 \%$ vol. when compared to $0.15 \%$ vol. for B20 (80D +20WCO), $0.19 \%$ vol. for B10 (90D $+10 \mathrm{WCO}$ ) and $0.23 \%$ vol. for pure diesel mode for the similar injection operating pressure.

\section{Hydrocarbon Emissions}

Figure 5 shows the comparison in HC pollutions by changing IOP of 200, 225, 250 bar with neat diesel and WCO blends correspondingly. As the \% WCO in oil raises, hydrocarbon emissions also increase at all IOP when compared with pure diesel operation. Since maximum BTE was observed for pure diesel mode, hence the arrangement of $\mathrm{HC}$ content for pure diesel will be less than that of WCO blends. Moreover, as the IOP increases from 200 to 225 bar, the HC content decreases. At 225 bar, due to appropriate break-down and combination, the utmost percentage of carbon content burnt and formation of $\mathrm{HC}$ very much lowered. Additional enhance of IOP to 250 bar gives maximize the development of $\mathrm{HC}$ due to shorter delay time and rapid burning (Quadri et al., 2015). The least amount HC content was noticed for diesel mode at 225 bar i.e., $49 \mathrm{ppm}$ when compared to 54 ppm for B10 (90D +10WCO), $61 \mathrm{ppm}$ for B20 (80D $+20 \mathrm{WCO})$ and $64 \mathrm{ppm}$ for $\mathrm{B} 30(70 \mathrm{D}+30 \mathrm{WCO})$ for the same injection operating pressure.

\section{Nitrous Oxide Emissions}

Figure 6 gives the varying in NOx concentrations by changing IOP of 200, 225, 250 bar with neat diesel and WCO blends respectively. From the figure, it is given that as the percentage replacement WCO in diesel raises, NOx decreases at all IOP compared to diesel. Also, the amount of NOx greater from IOP of 200 to 225 bar, due to fast burning and elevated in-cylinder gas temperature, extreme pressure attained for high initial IOP. Additional rise of IOP to 250 bar decreases the NOx emissions due to incomplete burning gives minimum in-cylinder temperatures compared to IOP 225 bar. The least NOx content was noticed for B30 (70D +30WCO) i.e., 1110 ppm at 200 bar when compared to $1221 \mathrm{ppm}$ for B20 (80D +20WCO), 1305 ppm for B10 (90D +10WCO) and $1384 \mathrm{ppm}$ for pure diesel mode for the same injection operating pressure (Table 6).

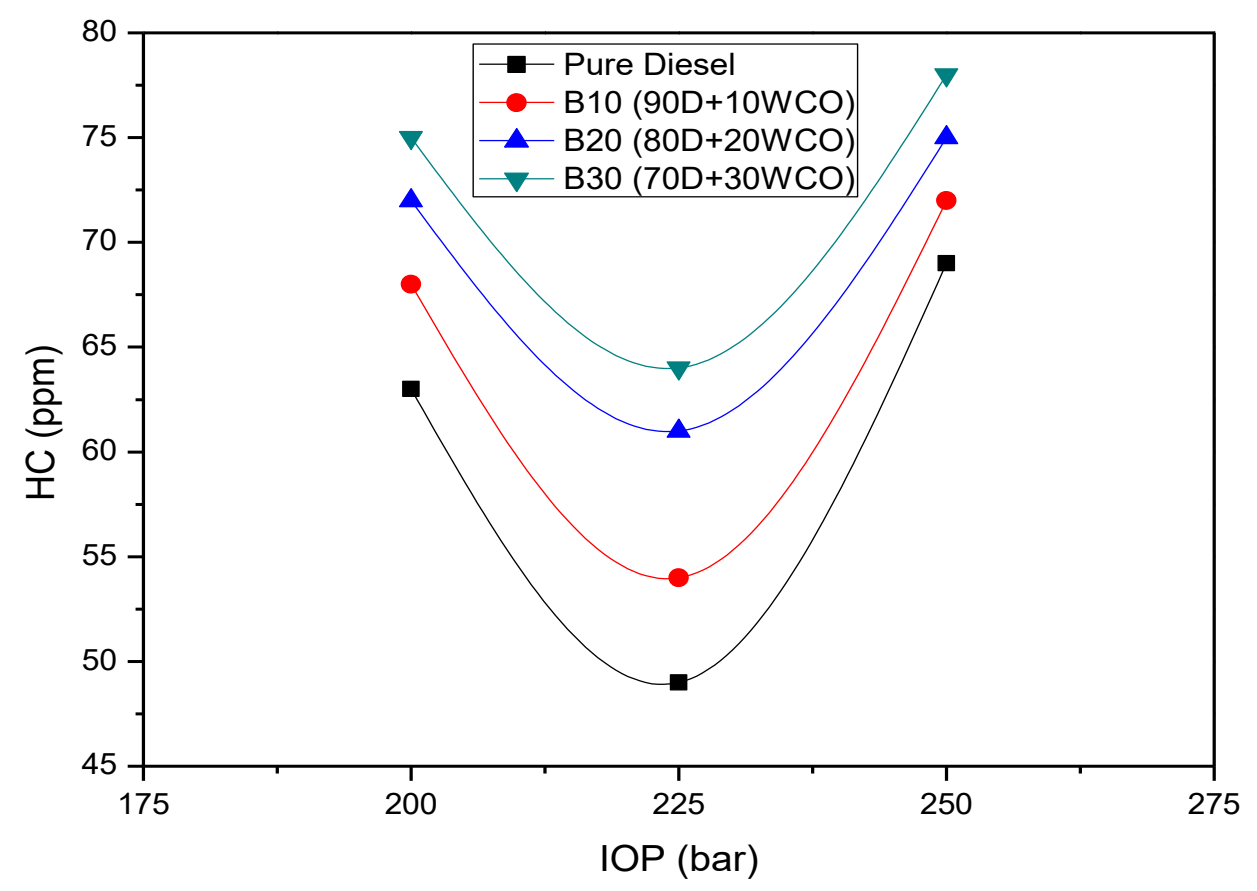

Fig. 5: Variation of $\mathrm{HC}$ emissions with IOP 


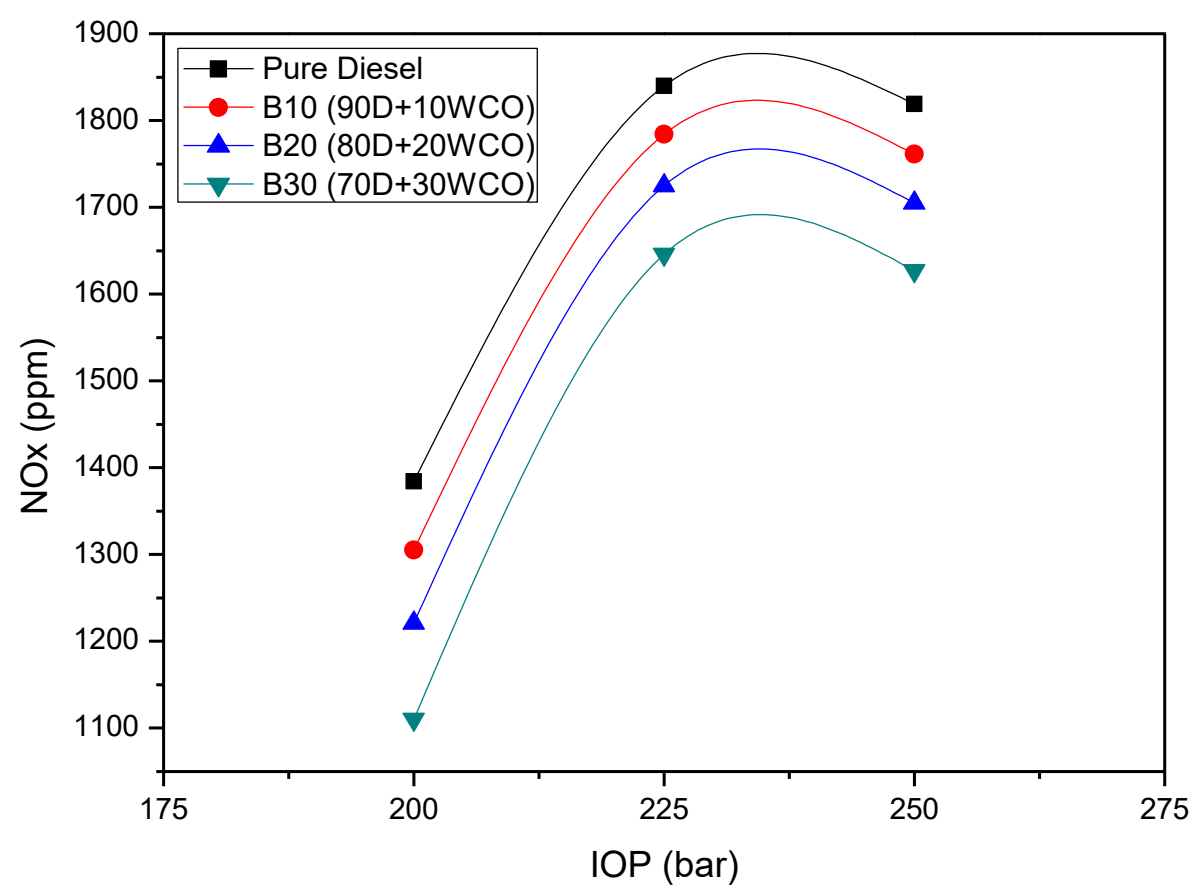

Fig. 6: Variation of NOx and IOP

Table 6: Nomenclature

\begin{tabular}{ll}
\hline WCO & Waste cooking oil \\
B10 & $10 \%$ blend of biodiesel \\
B20 & $20 \%$ blend of biodiesel \\
B30 & $30 \%$ blend of biodiesel \\
IOP & Injection operating pressure \\
CR & Compression ratio \\
BTDC & Before top dead center \\
BTE & Brake thermal efficiency \\
BSFC & Brake specific fuel consumption \\
CO & Carbon monoxide \\
HC & Hydrocarbons \\
NOx & Oxides of nitrogen \\
Ppm & parts per million \\
$\%$ vol. & Percentage volume \\
\hline
\end{tabular}

\section{Conclusion}

Based on analysis on performance and emission variables of single cylinder CI engine using WCO blended with conventional diesel, the following Judgments are furnished.

BTE raised by $7.61 \%$ when IOP increased from 200 to $225 \mathrm{bar}$ and decreased by $4.86 \%$ when IOP increased from 225 to 250 bar. Also, BTE declined as the percentage substitutions of WCO in diesel raised.

Brake specific fuel utilization decreased by $23.17 \%$ when IOP improved from 200 to 225 bar and increased by $8.72 \%$ when IOP improved from 225 to 250 bar. Further, BSFC rises with rise in proportion substitutions of WCO in diesel.
Carbon monoxide emissions decreased by $27.48 \%$ when IOP amplified from 200 to 225 bar and increased by $13.97 \%$ when IOP improved from 225 to 250 bar. Additionally, $\mathrm{CO}$ content decreases with increase in percentage substitutions of WCO in diesel because of less carbon content present in WCO biodiesel.

Hydrocarbon emissions decreased by $18.21 \%$ when IOP raised from 200 to 225 bar and increased by $29.74 \%$ when IOP increased from 225 to 250 bar. Since greatest brake thermal efficiency was observed for pure diesel operation, hence the formation of $\mathrm{HC}$ content for pure diesel less than that of WCO blends.

NOx emissions increased by $39.8 \%$ when IOP increased from 200 to 225 bar and a little decreased by $1.2 \%$ when IOP increased from 225 to 250 bar. Moreover, as the concentration substitutions of WCO in diesel raised, NOx emissions decreased at all IOP.

Finally, from the above Judgments, satisfactory IOP was found to be at 225 bar for all blends when compared to pure diesel due to marginal drop performance of CI engine and lower exhaust emissions.

It is also discovered that emissions decreased with increase in WCO blend percentage however, there was slightly less in the performance of the engine.

\section{Acknowledgment}

Authors acknowledge the Qassim University, College of Engineering Unaizah in extending Lab services to perform the experimentation. 


\section{Author's Contributions}

All authors equally contributed in this study.

\section{Ethics}

This script is unique and includes private matter. Authors states that no ethical concerns may occur after publication of document.

\section{References}

Anand, R., Kannan, G. R., \& Karthikeyan, P. (2012, November). A Study of the Performance Emission and Combustion Characteristics of a DI Diesel Engine Using Waste Cooking Oil Methyl Ester-Ethanol Blends. In ASME International Mechanical Engineering Congress and Exposition (Vol. 45226, pp. 935-942). American Society of Mechanical Engineers.

Arai, M., Tabata, M., Hiroyasu, H., \& Shimizu, M. (1984). Disintegrating process and spray characterization of fuel jet injected by a diesel nozzle. SAE Transactions, 358-371.

Aydin, H., \& Ilk1lic, C. (2010). Effect of ethanol blending with biodiesel on engine performance and exhaust emissions in a CI engine. Applied Thermal Engineering, 30(10), 1199-1204.

Bari, S., Yu, C. W., \& Lim, T. H. (2004). Effect of fuel injection timing with waste cooking oil as a fuel in a direct injection diesel engine. Proceedings of the Institution of Mechanical Engineers, Part D: Journal of Automobile Engineering, 218(1), 93-104.

Barik, D., \& Murugan, S. (2014a). Investigation on combustion performance and emission characteristics of a DI (direct injection) diesel engine fueled with biogas-diesel in dual fuel mode. Energy, 72, 760-771.

Barik, D., \& Murugan, S. (2014b). Simultaneous reduction of NOx and smoke in a dual fuel DI diesel engine. Energy Conversion and Management, 84, 217-226.

Canakci, M. (2007). The potential of restaurant waste lipids as biodiesel feedstocks. Bioresource Technology, 98(1), 183-190.

Chen, P. C., Wang, W. C., Roberts, W. L., \& Fang, T. (2013). Spray and atomization of diesel fuel and its alternatives from a single-hole injector using a common rail fuel injection system. Fuel, 103, 850-861.

Chhetri, A. B., Watts, K. C., \& Islam, M. R. (2008). Waste cooking oil as an alternate feedstock for biodiesel production. Energies, 1(1), 3-18.
Gumus, M. (2010). A comprehensive experimental investigation of combustion and heat release characteristics of a biodiesel (hazelnut kernel oil methyl ester) fueled direct injection compression ignition engine. Fuel, 89(10), 2802-2814.

Hwang, J., Qi, D., Jung, Y., \& Bae, C. (2014). Effect of injection parameters on the combustion and emission characteristics in a common-rail direct injection diesel engine fueled with waste cooking oil biodiesel. Renewable Energy, 63, 9-17.

Jaichandar, S., \& Annamalai, K. (2013). Combined impact of injection pressure and combustion chamber geometry on the performance of a biodiesel fueled diesel engine. Energy, 55, 330-339.

Kuti, O. A., Zhu, J., Nishida, K., Wang, X., \& Huang, Z. (2013). Characterization of spray and combustion processes of biodiesel fuel injected by diesel engine common rail system. Fuel, 104, 838-846.

Lapuerta, M., Rodríguez-Fernández, J., \& Agudelo, J. R. (2008). Diesel particulate emissions from used cooking oil biodiesel. Bioresource Technology, 99(4), 731-740.

Lin, Y. C., Hsu, K. H., \& Chen, C. B. (2011). Experimental investigation of the performance and emissions of a heavy-duty diesel engine fueled with waste cooking oil biodiesel/ultra-low sulfur diesel blends. Energy, 36(1), 241-248.

Meng, X., Chen, G., \& Wang, Y. (2008). Biodiesel production from waste cooking oil via alkali catalyst and its engine test. Fuel Processing Technology, 89(9), 851-857.

Muralidharan, K., \& Vasudevan, D. (2011). Performance, emission and combustion characteristics of a variable compression ratio engine using methyl esters of waste cooking oil and diesel blends. Applied Energy, 88(11), 3959-3968.

Phan, A. N., \& Phan, T. M. (2008). Biodiesel production from waste cooking oils. Fuel, 87(1718), 3490-3496.

Qi, D. H., Chen, H., Geng, L. M., \& Bian, Y. Z. (2011). Effect of diethyl ether and ethanol additives on the combustion and emission characteristics of biodiesel-diesel blended fuel engine. Renewable Energy, 36(4), 1252-1258.

Quadri, S. A. P., Masood, M., \& Kumar, P. R. (2015). Effect of pilot fuel injection operating pressure in hydrogen blended compression ignition engine: An experimental analysis. Fuel, 157, 279-284. 
Radu, R., Petru, C., Edward, R., \& Gheorghe, M. (2009). Fueling an DI agricultural diesel engine with waste oil biodiesel: Effects over injection, combustion and engine characteristics. Energy Conversion and Management, 50(9), 2158-2166.

Sanli, H., Canakci, M., Alptekin, E., Turkcan, A., \& Ozsezen, A. N. (2015). Effects of waste frying oil based methyl and ethyl ester biodiesel fuels on the performance, combustion and emission characteristics of a DI diesel engine. Fuel, 159, 179-187.
Sayin, C., Ozsezen, A. N., \& Canakci, M. (2010). The influence of operating parameters on the performance and emissions of a DI diesel engine using methanol-blended-diesel fuel. Fuel, 89(7), 1407-1414.

Valente, O. S., Pasa, V. M. D., Belchior, C. R. P., \& Sodré, J. R. (2012). Exhaust emissions from a diesel power generator fuelled by waste cooking oil biodiesel. Science of the Total Environment, $431,57-61$ 